\title{
CYTOTOXIC ACTIVITY OF TWO LIMONOIDS ISOLATED FROM SWIETENIA MAHAGONI BY USING BRINE SHRIMP LETHALITY BIOASSAY
}

\author{
AKM SHAHIDUR RAHMAN ${ }^{1}$, AK AZAD CHOWDHURY ${ }^{2}$, HOSSAIN REZA ${ }^{4}$, MOHAMMAD SHAWKAT ALI ${ }^{2}$, MANZURUR \\ RAHMAN SHAH CHOUDHURY ${ }^{4}$, LUTFUN NAHAR ${ }^{3}$ AND SATYAJIT D. SARKER ${ }^{3}$ \\ Department of Pharmacology and Therapeutics, Khwaja Yunus Ali Medical College, Enayetpur Sharif, Post- \\ Enyetpur, Sirajgonj-6751 ${ }^{1}$, Department of Clinical Pharmacy and Pharmacology, Faculty of Pharmacy, University of \\ Dhaka, Dhaka 1000, Bangladesh², School of Biomedical Sciences, University of Ulster, Cromore Road, Coleraine \\ BT52 1SA, Co. Londonderry, Northern Ireland, UK ${ }^{3}$, Department of Physiology, Khwaja Yunus Ali Medical College, \\ Enayetpur Sharif, Post- Enyetpur, Sirajgonj-67514.
}

\begin{abstract}
Solvent partitioning followed by column chromatography of the MeOH extract of the seeds of Swietenia mahagoni afforded two limonoids, swietenolide (compound 1) and 2-hydroxy-3-O-tigloylswietenolide (compound 2), later one is new compound. The compounds were identified by spectroscopic means. The cytotoxic activity of these compounds was assessed by using the conventional brine shrimp lethality bioassay. While both compounds were found to have moderate cytotoxic activity, compound 2 displayed overall more potent activity than compound 1.
\end{abstract}

Key words: Cytotoxic, Limonoid, Swietenia mahagoni, Brine shrimp lethality bioassay

(Bangladesh J Physiol Pharmacol 2007; 23(1\&2) : 1-6)

\section{INTRODUCTION}

Swietenia mahagoni (L.) Jacq., a deciduous and economically important timber tree commonly known as 'Mahogani', belongs to the family Meliaceae, which has 146 genera and about 1500 species $^{1}$. S. mahagoni is native to a number of North and South American countries including USA, Cuba, Haiti, Jamaica, San Domingo and the Bahamas, and has been distributed elsewhere. Nowadays, it is widely cultivated in both plane land and hill tracts of Bangladesh. Traditionally, various parts of this plant have been used in the treatment of fever, diabetes, malaria, hypertension and tuberculosis, and as an abortifacient, antiseptic, astringent, depurative, purgative and tonic ${ }^{2-4}$. The antifeedant activity of the limonoids from this plant has been reported recently ${ }^{5}$. The extract of this plant showed ameliorative effects on diabetic mice $^{6}$, antimicrobial properties ${ }^{7,8}$, platelet aggregation inhibitory ${ }^{9}$ and anti-HIV activities ${ }^{10}$. Chlorogenic acid from the methanol extract of this plant displayed human immunodeficiency virus protease inhibitory activity ${ }^{11}$. Previous phytochemical investigations on this species led to isolation and identification of more

Address of Correspondence: Dr. AKM Shahidur Rahman, Assistant Professor, Department of Pharmacology, Khwaja Yunus Ali Medical College, Enayetpur, Sirajgonj. E-mail: drshaheen20032003@yahoo.com than 45 limonoids belonging to the structural classes andirobin, gendunin, mexicanolide and phragmalin, triterpens, tetranortriterpenes and chlorogenic acid $^{4,5,9,11,12}$. Two limonoids swietenolide (compound 1) and 2-hydroxy-3-O-tigloylswietenolide (compound 2) previously isolated from from the seeds of Swietenia mahagonii were found to have promising antibacterial against a number of multiple drug resistant (MDR) bacterial strains ${ }^{13}$. As a part of our on-going phytochemical and bioactivity studies on Bangladeshi plants $^{14-19}$, we now report on the isolation, identification and cytotoxic properties of two limonoids, swietenolide (compound 1) and 2-hydroxy-3-O-tigloylswietenolide (compound 2), the latter being a new natural product, from Swietenia mahagoni. The cytotoxic properties were determined by using brine shrimp lethality

\section{MATERIALSAND METHODS}

Bioassay. This bioassay is indicative cytotoxicity and a wide range of pharmacological activity of the compounds

\section{General procedures}

NMR spectra were recorded in $\mathrm{CD}_{3} \mathrm{OD}$ on a Bruker DRX $500 \mathrm{MHz}$ NMR Spectrometer $\left(500 \mathrm{MHz}\right.$ for ${ }^{1} \mathrm{H}$ and $125 \mathrm{MHz}$ for ${ }^{13} \mathrm{C}$ ) using residual solvent peak as internal standard. FABMS analyses were performed, on a Finnigan MAT95 spectrometer. 


\section{Plant material}

The seeds of Swietenia mahagoni (L.) Jacq. were collected from Sirajgonj, Bangladesh in December, 2004. The plant was taxonomically identified by the Department of Botany, University of Dhaka, where a voucher specimen (no.18) has been retained.

\section{Extraction and isolation of compounds}

The dried and ground seeds of S. mahagoni (850 g) were percolated in methanol $(2 \times 1.5 \mathrm{~L})$ for 3 days at room temperature with occasional shaking and stirring. The resulting extract was filtered through a fresh cotton plug and finally with a Whatman no.1 filters paper. The volume of filtrate was concentrated using a rotary evaporator at low temperature and reduced pressure to obtain a reddish-brown gummy extract $(58.74 \mathrm{~g})$. A portion of the extract $(10 \mathrm{~g})$ was suspended in $5 \% \mathrm{MeOH}$ in water (100 $\mathrm{mL})$, and partioned against $n$-hexane $(3 \times 100 \mathrm{~mL})$ to yield $n$-hexane fraction $(1.9 \mathrm{~g})$ and aqueous fraction $(6.7 \mathrm{~g})$. The aqueous fraction was further partioned against chloroform $(3 \times 100 \mathrm{~mL})$ and then ethyl acetate (EtOAc) $(3 \times 100 \mathrm{~mL})$ to produce $3.0 \mathrm{~g}$ of ethyl acetate fraction. A portion of the EtOAc fraction $(1.5 \mathrm{~g})$ was subjected to column chromatography on Kieselgel 60, mesh 70- 230 (mobile phase $=$ dichloromethane $(\mathrm{DCM})$ and $\mathrm{MeOH}$ of increasing polarity), which resulted in ten fractions. Compounds 1 (22 mg, $\left.R_{f}=5.0\right)$ and $2\left(R_{f}=2.5,17.5 \mathrm{mg}\right.$ ) were obtained from the column fractions 3 and 5 , respectively, on evaporation of solvent, and after being washed with petroleum ether. The purity of the compounds were assessed by TLC using solvent systems, DCM: $\mathrm{MeOH}=$ 4:1, and DCM: $\mathrm{MeOH}=3: 2$, respectively, and vanillinsulphuric acid as the spray reagent.

\section{Swietenolide (compound 1)}

Reddish-brown amorphous solid (yield 0.00517\%); 22.0 mg; m.p. $175-178{ }^{\circ} \mathrm{C}$; FABMS m/z 509 [M + Na $]^{+} ;{ }^{1} \mathrm{H}$ NMR (500 MHz, CDCl 3 and ${ }^{13} \mathrm{C}$ NMR (125 MHz, CDCl ${ }_{3}$ ) as published data [20], Table-I and Figure-1.

2-Hydroxy-3-O-tigloylswietenolide (compound 2)

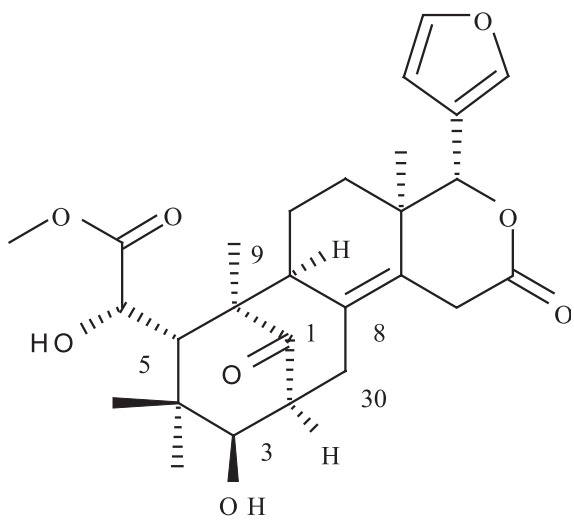

Compound 1 : Swietenolide

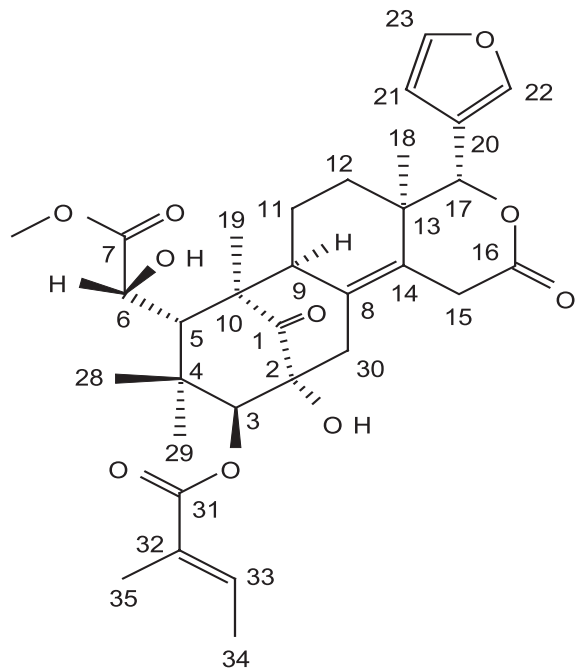

Compound 2 : 2-Hydroxy-3-O-tigloylswietenolide

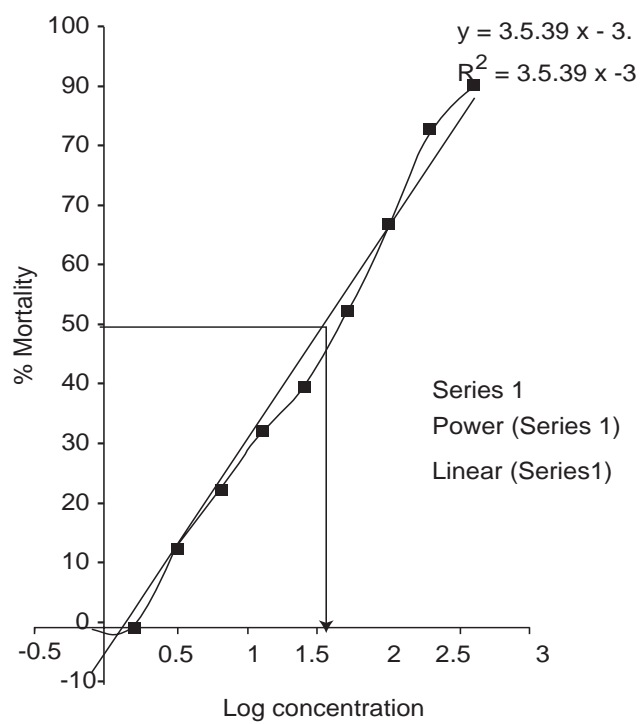

Fig.-1: Structure of the compound 1 and 2

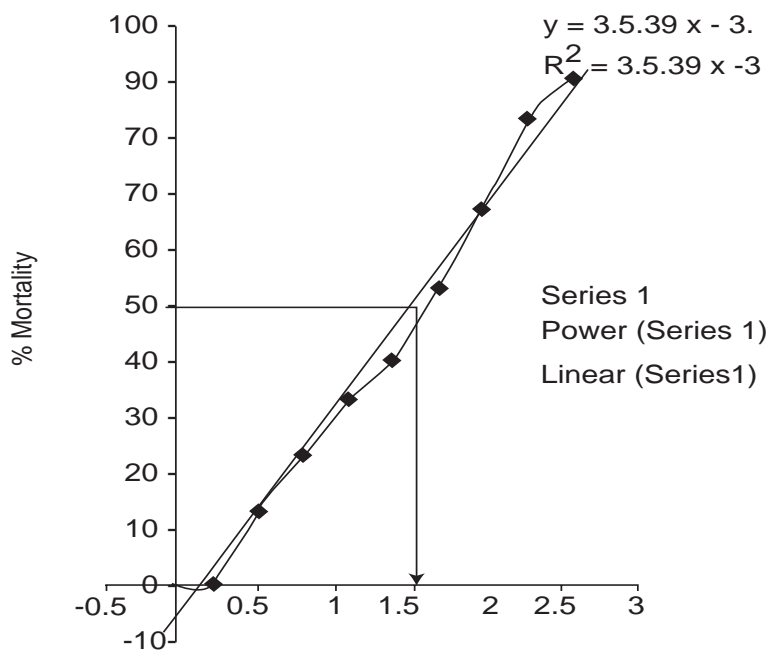


Table-I

${ }^{1} \mathrm{H}$ NMR (500 MHz, coupling constant $\mathrm{J}$ in $\mathrm{Hz}$ in parentheses) and ${ }^{13} \mathrm{C}$ NMR $(125 \mathrm{MHz})$ data of compounds 1 and 2 , and ${ }^{1} \mathrm{H}_{-}{ }^{13} \mathrm{C}$ long-range $\left(\mathrm{J}\right.$ and $\left.{ }^{3} \mathrm{~J}\right) \mathrm{HMBC}$ key correlation of 2

\begin{tabular}{|c|c|c|c|c|c|c|}
\hline \multirow[t]{3}{*}{ Position } & \multicolumn{4}{|c|}{ Chemical shift in ppm } & \multicolumn{2}{|c|}{ HMBC correlation in 2} \\
\hline & \multicolumn{2}{|r|}{${ }^{1}{ }_{H}$} & \multicolumn{2}{|c|}{${ }^{13} \mathrm{C}$} & \multirow{2}{*}{\multicolumn{2}{|c|}{$2 J \quad 3 j$}} \\
\hline & 1 & 2 & 1 & 2 & & \\
\hline 1 & - & - & 219.0 & 216.0 & - & - \\
\hline 2 & $3.02 \mathrm{~m}$ & - & 50.0 & 78.9 & - & - \\
\hline 3 & 3.54 d (10.6) & $4.54 \mathrm{~s}$ & 78.5 & 80.2 & C-2, C-4 & $\begin{array}{l}\text { C-1, C- } 28, C-29 \\
\text { C-30, C-31 }\end{array}$ \\
\hline 4 & - & - & 39.6 & 39.0 & - & - \\
\hline 5 & $3.25 \mathrm{br} \mathrm{s}$ & $3.48 \mathrm{~s}$ & 44.0 & 45.0 & $C-4, C-6$ & $\begin{array}{l}\text { C-1, C-3, C-7, C-9, } \\
\text { C-19, C-28, C-29, }\end{array}$ \\
\hline 6 & $4.50 \mathrm{bd}$ & $4.61 \mathrm{bd}$ & 73.5 & 72.9 & - & $C-4, C-10$ \\
\hline 7 & - & - & 175.8 & 176.0 & - & - \\
\hline 8 & - & - & 129.0 & 123.6 & - & - \\
\hline 9 & $2.09 \mathrm{~m}$ & $2.10 \mathrm{~m}$ & 53.0 & 57.5 & - & C-1, C-12, C-14 \\
\hline 10 & - & - & 54.0 & 50.4 & - & - \\
\hline 11 & $1.14 \mathrm{~m}$ & $1.14 \mathrm{~m}$ & 29.1 & 29.7 & C-9, C-12 & - \\
\hline 12 & $1.78 \mathrm{~m}$ & $1.77 \mathrm{~m}$ & 17.9 & 19.1 & $C-11, C-13$ & - \\
\hline 13 & - & - & 38.2 & 39.0 & - & - \\
\hline 14 & - & - & 130.8 & 138.3 & - & - \\
\hline 15 & $\begin{array}{l}3.45 \mathrm{~d}(20.3) \\
3.98 \mathrm{~d}(20.3)\end{array}$ & $3.50 \mathrm{~m} 3.97 \mathrm{~m}$ & 33.1 & 34.0 & $C-16$ & - \\
\hline 16 & - & - & 171.4 & 170.0 & - & - \\
\hline 17 & $5.44 \mathrm{~s}$ & $5.53 \mathrm{~s}$ & 80.5 & 78.4 & $C-20$ & C-12, C-14, C-16 \\
\hline 18 & $0.95 \mathrm{~s}$ & $0.96 \mathrm{~s}$ & 17.9 & 18.0 & $C-13$ & C-12, C-14, C-17 \\
\hline 19 & $1.36 \mathrm{~s}$ & $1.42 \mathrm{~s}$ & 18.7 & 18.9 & $C-10$ & $C-1, C-5, C-9$ \\
\hline 20 & - & - & 120.8 & 121.0 & - & - \\
\hline 21 & $7.44 \mathrm{~s}$ & $7.54 \mathrm{~s}$ & 141.1 & 141.2 & $\mathrm{C}-20, \mathrm{C}-23$ & $\mathrm{C}-22, \mathrm{C}-17$ \\
\hline 22 & $6.36 \mathrm{~s}$ & $6.37 \mathrm{~s}$ & 109.8 & 110.1 & - & $C-21, C-23$ \\
\hline 23 & $7.37 \mathrm{~s}$ & $7.43 \mathrm{~s}$ & 142.9 & 143.0 & $C-21$ & $C-22$ \\
\hline 28 & $0.95 \mathrm{~s}$ & $1.11 \mathrm{~s}$ & 23.2 & 21.3 & C-4 & $C-3, C-5, C-29$ \\
\hline 29 & $0.84 \mathrm{~s}$ & $0.88 \mathrm{~s}$ & 23.6 & 22.8 & $C-4$ & $C-3, C-5, C-28$ \\
\hline 30 & 2.09 m3.14 m & $2.60 \mathrm{bs}$ & 33.8 & 34.4 & C-2, C-8 & - \\
\hline 31 & - & - & - & 169.8 & - & - \\
\hline OMe & $3.78 \mathrm{~s}$ & $3.75 \mathrm{~s}$ & 53.2 & 53.3 & - & C-7 \\
\hline 32 & - & - & - & 127.7 & - & \\
\hline 33 & - & $6.85 q(7.4)$ & - & 143.2 & C-32 & C-31, C-35 \\
\hline 34 & - & $1.73 \mathrm{~d}(7.4)$ & - & 14.6 & $C-33$ & $C-32$ \\
\hline 35 & - & $1.80 \mathrm{~s}$ & - & 11.7 & C-32 & $C-31, C-33$ \\
\hline
\end{tabular}

Spectra obtained in CDC3 
Bangladesh Journal of Physiology and Pharmacology

Table 2.1

Effects of compound 1 on brine shrimp nauplii

\begin{tabular}{llccccc}
\hline $\begin{array}{l}\text { Concentration(C) } \\
(\mu \mathrm{g} / \mathrm{ml})\end{array}$ & Log C & \multicolumn{3}{c}{ \% Mortality } & \multicolumn{2}{c}{$\begin{array}{c}\text { LC }_{50}(\mu \mathrm{g} / \mathrm{ml}) \\
\text { SMS1 }\end{array}$} \\
\cline { 3 - 6 } & & Group-A & Group-B & Group-C & Average \\
\hline 400 & 2.60206 & 100 & 100 & 100 & 100 & 33.46 \\
200 & 2.30103 & 100 & 90 & 90 & 93 & \\
100 & 2.00000 & 80 & 70 & 80 & 77 & \\
50 & 1.69897 & 60 & 70 & 50 & 60 & \\
25 & 1.39794 & 40 & 40 & 50 & 43 & \\
12.5 & 1.09691 & 20 & 20 & 20 & 20 & \\
6.25 & 0.79588 & 10 & 20 & 10 & 13 & \\
3.125 & 0.49485 & 00 & 10 & 00 & 3 & \\
1.562 & 0.19382 & 00 & 00 & 00 & 00 & \\
0.781 & -0.10720 & 00 & 00 & 00 & 00 & \\
\hline
\end{tabular}

Table 2.1

Effects of compound 2 on brine shrimp nauplii

\begin{tabular}{lcccccc}
\hline $\begin{array}{l}\text { Concentration }(\mathrm{C}) \\
(\mu \mathrm{g} / \mathrm{ml})\end{array}$ & Log C & \multicolumn{3}{c}{ \% Mortality } & \multicolumn{2}{c}{$\begin{array}{c}\text { LC }_{50}(\mu \mathrm{g} / \mathrm{ml}) \\
\text { SMS2 }\end{array}$} \\
\cline { 3 - 7 } & & Group-A & Group-B & Group-C & Average \\
\hline 400 & 2.60206 & 100 & 100 & 100 & 100 & 29.13 \\
200 & 2.30103 & 100 & 100 & 100 & 100 & \\
100 & 2.00000 & 90 & 80 & 80 & 83 & \\
50 & 1.69897 & 60 & 70 & 70 & 67 & \\
25 & 1.39794 & 40 & 50 & 50 & 47 & \\
12.5 & 1.09691 & 30 & 20 & 20 & 23 & \\
6.25 & 0.79588 & 10 & 20 & 20 & 17 & \\
3.125 & 0.49485 & 00 & 10 & 10 & 7 & \\
1.562 & 0.19382 & 00 & 10 & 00 & 3 & \\
0.781 & -0.10720 & 00 & 00 & 00 & 00 & \\
\hline
\end{tabular}

White crystals (yield 0.00411\%); 17.5 mg; m.p. 214$216{ }^{\circ} \mathrm{C}$; FABMS m/z $607[\mathrm{M}+\mathrm{Na}]^{+}$; HR-FABMS m/z 607.2518 calculated 607.2519 for $\mathrm{C}_{32} \mathrm{H}_{40} \mathrm{O}_{10} \mathrm{Na}$. ${ }^{1} \mathrm{H}$ NMR (500 MHz, $\mathrm{CDCl}_{3}$ and ${ }^{13} \mathrm{C}$ NMR (125 MHz, CDCl 3 ) Table 1 and Figure 1.

\section{Cytotoxic activity}

Preparation of sea water- $38 \mathrm{gm}$ salt (pure $\mathrm{NaCl}$ ) was weighed, dissolved in 1 liter of distilled water and filtered off to get clear solution.

Hatching of brine shrimps- Artemia salina leach (brine shrimp eggs) collected from pet shop was used as the test organism. Sea water was taken in the small tank and shrimp eggs were added one side of the tank and then this side was covered. One day (24 hours) was allowed to hatch the shrimps and to be matured as nauplii. Constant oxygen supply was provided throughout the hatching time. The hatched shrimps were attracted to the lamp through the perforated dam and with the help of Pasteur pipette 10 living shrimps were added to each of the test tubes containing $5 \mathrm{ml}$ of sea water.

\section{Preparation of the test solution}

$2 \mathrm{mg}$ of each sample (compound 1 and compound 2) was dissolved in specific volume of DMSO 
(Dimethylsulfoxide) to obtain the desired concentration of the prepared solution as $2000 \mu \mathrm{gm} / 30 \mu \mathrm{l}$. Then a series of solutions of lower concentrations were prepared from this solution serial dilution with DMSO. Thus the concentrations of the solutions were obtained as $2000 \mu \mathrm{g} /$ $30 \mu \mathrm{l}, 1000 \mu \mathrm{g} / 30 \mu \mathrm{l}, 500 \mu \mathrm{g} / 30 \mu \mathrm{l}, 250 \mu \mathrm{g} / 30 \mu \mathrm{l}, 125 \mu \mathrm{g} / 30 \mu \mathrm{l}$, $62.5 \mu \mathrm{g} / 30 \mu \mathrm{l}, 31.25 \mu \mathrm{g} / 30 \mu \mathrm{l}, 15.63 \mu \mathrm{g} / 30 \mu \mathrm{l}, 7.81 \mu \mathrm{g} / 30 \mu \mathrm{l}$, $3.90 \mu \mathrm{g} / 30 \mu \mathrm{l}$. From each of these solutions $30 \mu \mathrm{l}$ were added to the pre-marked test tubes containing $5 \mathrm{ml}$ of sea water and 10 shrimp nauplii. So, the final concentration of samples in the test tubes were $400 \mu \mathrm{g} /$ $30 \mu \mathrm{l}, 200 \mu \mathrm{g} / 30 \mu \mathrm{l}, 100 \mu \mathrm{g} / 30 \mu \mathrm{l}, 50 \mu \mathrm{g} / 30 \mu \mathrm{l}, 25 \mu \mathrm{g} / 30 \mu \mathrm{l}$, $12.5 \mu \mathrm{g} / 30 \mu \mathrm{l}, 6,25 \mu \mathrm{g} / 30 \mu \mathrm{l}, 3.125 \mu \mathrm{g} / 30 \mu \mathrm{l}, 1.56 \mu \mathrm{g} / 30 \mu \mathrm{l}$, $0.78 \mu \mathrm{g} / 30 \mu \mathrm{l}$ respectively.

\section{Preparation of the control group}

Vincristine sulfate served as the positive control.

\section{Preparation of the negative control}

As for negative control, $30 \mu$ of DMSO was added to each of three pre-marked glass vials containing $5 \mathrm{ml}$ of simulated sea water and 10 shrimp nauplii to use for negative control. If the brine shrimps in these vials show a rapid mortality rate, then the test tube is considered as the nauplii died due to some reason other than the cytotoxicity of the compounds.

Counting of nauplii and determination of $\mathrm{LC}_{50}$ - After 24 hours, the vials were observed using a magnifying glass and number of survived nauplii in each vial was counted. From this data, the percent (\%) of the lethality of the brine shrimp nauplii was calculated for each concentration. Percentage (\%) of the mortality of brine shrimp against log concentration were plotted on graph paper by using SPSS Software and Microsoft Office Excel to determine the LC $_{50}$ of the compound $\mathbf{1}$ and compound 2 .

\section{RESULTS AND DISCUSSION}

Solvent partitioning followed by column chromatography of the $\mathrm{MeOH}$ extract of the seeds of Swietenia mahagoni afforded two limonoids, swietenolide (compound 1) [20] and 2-hydroxy-3-Otigloylswietenolide (compound 2). The compounds were identified by spectroscopic means.

The FABMS spectrum of compound 1 revealed the pseudomolecular ion $[\mathrm{M}+\mathrm{Na}]^{+}$at $\mathrm{m} / \mathrm{z} 509$ corresponding to the molecular formula $\mathrm{C}_{27} \mathrm{H}_{34} \mathrm{O}_{8}$. The ${ }^{1} \mathrm{H}$ and ${ }^{13} \mathrm{C}$ NMR data (Table 1) of compound $\mathbf{1}$ were in total agreement with the data published for the known limonoid swietenolide (compound $\mathbf{1})^{20}$. The HR-FABMS spectrum of compound 2 showed the pseudomolecular ion $[\mathrm{M}+\mathrm{Na}]^{+}$ at $\mathrm{m} / \mathrm{z}$ 607.2518, and confirmed the molecular formula $\mathrm{C}_{32} \mathrm{H}_{40} \mathrm{O}_{10}$ for this compound. The ${ }^{1} \mathrm{H}$ and ${ }^{13} \mathrm{C} N M R$ spectra (Table 1 ) of compound 2 were quite similar to those of compound $\mathbf{1}$, with the notable exceptions that there were signals for a tigloyl moiety $\left(?_{\mathrm{H}} 6.85,1.73\right.$, $\left.1.80 ; ?_{\mathrm{C}} 169.8,127.7,143.2,14.6,11.7\right)$, the signal for the C-2 methine (as in compound 1) was absent, and an additional oxygenated quarternary carbon signal ( $?_{C}$ 78.9) appeared. These data indicated hydroxylation at C-2, and the presence of an $\mathrm{O}$-tigloyl functionality, which could be placed at $\mathrm{C}-3$, and confirmed from the ${ }^{3} \mathrm{~J}^{1} \mathrm{H}-{ }^{13} \mathrm{C} \mathrm{HMBC}$ correlation (Table 1) between $\mathrm{H}-3\left(?_{\mathrm{H}} 4.54\right)$ and the tigloyl carbonyl (C-31, ? $\mathrm{C}$ 169.8). The ${ }^{1} \mathrm{H}$ and ${ }^{13} \mathrm{C}$ NMR data (Table 1) of 2 were also comparable with the data published for the similar compound, 2-hydroxy-3-Otigloyl-6-O-acetylswietenolide ${ }^{21}$ with the exception of the acetyl signal. Thus, compound $\mathbf{2}$ was identified exclusively as 2-hydroxy-3-O-tigloylswietenolide, which is a new natural product.

In this bioassay, two pure compounds (Compound 1 \& Compound 2) isolated from the ethyl acetate fraction of seeds of Swietenia mahagoni were showed positive results indicating that the compounds are more or less biologically active. Each of the test samples were showed different mortality rates at different concentrations.

The mortality rate of brine shrimp was found increased with the increasing concentration of the samples. A plot of log of concentration versus percent mortality on the graph paper produced an approximately linear correlation between them. From the graph, the concentration at which fifty percent mortality $\left(\mathrm{LC}_{50}\right)$ of the brine shrimp nauplii was determined by extrapolation.

The $L_{50}$ values for the pure compounds (Compound 1 and Compound 2) were found 33.46 and $29.13 \mu \mathrm{g} / \mathrm{ml}$ respectively, indicating that these compounds are moderately active against brine shrimp (Table 2.1 and 2.2, Figure 2.1, 2.2 and 2.3).

\section{CONCLUSION}

Swietenolide (compound 1) and 2-hydroxy-3-Otigloylswietenolide (compound 2) showed significant cytotoxic activity by using brine shrimp lethality bioassay, which is indicative cytotoxicity and a wide range of pharmacological activity of the compounds and this finding will certainly contribute to the on-going search for new anticancer agents to fight against bacterial infections caused by MDR bacterial strains.

\section{ACKNOWLEDGEMENTS}

We are grateful to Dr. Mohammad Shawkat Ali, Associate Professor, Department of Clinical Pharmacy and Pharmacology, University of Dhaka for giving us a scope to utilize his Pharmacology Research Laboratory for isolation, purification of the compounds and their biological activity.

We thank the EPSRC National Mass Spectrometry Service Centre (Department of Chemistry, University of Wales Swansea, Swansea, Wales, UK) for MS analyses. 


\section{REFERENCES}

1. GRIN Database (2008) USDA, ARS, National Genetic Resources Program. Germplasm Resources Information Network - (GRIN) [Online Database], National Germplasm Resources Laboratory, Beltsville, Maryland. URL: http:// www.ars-grin.gov/cgi-bin/npgs/html/gnlist.pl?704

2. Dr. Duke's Phytochemical and Ethnobotanical Databases (2008). URL: http://www.ars-grin.gov/cgi-bin/duke/ ethnobot.pl

3. Darziel JM. The Useful Plants of West Tropical Africa; The Crown Agents for the Colonies, London, 1937: pp 235.

4. Chen X-Y, Wang X-N, Fan C-Q, Yin S, Yue J-M. Swiemahogins $A$ and $B$, two novel limonoids from Swietenia mahogani, Tetrahedron Letters 48; 2007: 74807484.

5. Abdelgaleil SAM, Doe M, Morimoto Y, Nakatani M. Rings B, D-seco limonoids from the leaves of Swietenia mahogani, Phytochemistry 67; 2006: 452-458.

6. Li DD, Chen JH, Chen Q, Li GW, Chen J, Yue JM, Chen ML, Wang XP, Shen JH, Shen X, Jiang HL. Swietenia mahagony extract shows agonistic activity to PPAR gamma and gives ameliorative effects on diabetic $\mathrm{db} / \mathrm{db}$ mice, Acta Pharmacologica Sinica 26; 2005: 220-222.

7. Guon E, Cunnigham G, Chu D, Nguyen C, Miles D. Antibacterial and antifungal activity of Indoseian ethnomedical plants, Fitoterapia 76; 2003: 592-596.

8. Govindachari TR, Suresh G, Banumathy B, Masilamani S, Gopalakrishnan G, Kumari GNK. Antifungal activity of some $B, D$-seco limonoids from teo meliaceous plants, Journal of Chemical Ecology 25; 1999: 923-933.

9. Ekimoto H, Irie Y, Araki Y, Han GQ, Kadota S, Kikuchi T. Platelet aggregation inhibitors from seeds of Swietenia mahagoni - inhibition of in vitro and in vivo platelet activating factor-induced effects of tetranortriterpenoids related to swietenine and swietenolide, Planta Medica 57; 1991: 5658.

10. Otake T, Mori H, Morimoto M, Ueba N, Sutardjo S, Kusumoto IT, Hattori M, Namba T. Screening of Indonesian plant extracts dor anti-human-immunodefficiency-virus type-1 (HIV-1) activity, Phytotherapy Research 9; 1995: 6-10.

11. Matsuse IT, Nakabayashi T, Lim YA, Hussein GME, Miyashiro H, Kakiuchi N, Hattori M, Stardjo S, Shimotohno K. A human immunodefficiency virus protease inhibitory substance from Swietenia mahagoni, Phytotherapy Research 11; 1997: 433-436.

12. Murthy YLN, Jairaj MA, Srinivas ASSV. New triterpenes from Swietenia mahagoni Linn.9. identification of crystalline constituents and structure elucidation of a new triterpene, Indian Journal of Chemistry Section B - Organic Chemistry Including Medicianl Chemistry 30; 1991: 462465.

13. Rahman, AKMS. Bioactivity guided investigation on Swietenia mahagoni for active principles against multidrugs resistant group A beta haemolyticus and other pathogenic bacteria, M. Phil. Thesis, Department of Clinical Pharmacy and Pharmacology, University of Dhaka; 2008: 68.

14. Ali HA, Chowdhury AKA, Rahman AKM, Borkowski T, Nahar L, Sarker SD. Pachypodol, a Flavonol from the Leaves of Calycopteris floribunda, Inhibits the Growth of CaCo 2 Colon Cancer Cell Line in vitro, Phytotherapy Research; 2008: (in press).

15 Rahman MM, Gray AI, Kondker P, Sarker SD. The antibacterial and antifungal activities of the constituents of Flemingia paniculata, Pharmaceutical Biology; 2008: (in press).

16 Datta BK, Nahar L, Rahman MM, Gray AI, Auzi AA, Sarker SD. Polygosumic acid, a new cadinane sesquiterpene, from Polygonum viscosum inhibits the growth of drugresistant Escherichia coli and Staphylococcus aureus (MRSA) in vitro, Journal of Natural Medicine 61; 2007: 391-396.

17. Saha A, Masud MA, Bachar SC, Kundu JK, Nahar L, Datta BK, Sarker SD. Analgesic and anti-inflammatory activities of the extracts of Phyllanthus reticulatus in mice model, Pharmaceutical Biology 45; 2007: 355-359.

18. Uddin SJ, Shilpi JA, Byres M, Middleton M, Shoeb M, Nahar L, Sarker SD. Swarnalin and cis-swarnalin, two new tetrahydrofuran derivatives with free radical scavenging activity, from the aerial parts of Cuscuta reflexa, Natural Products Research 21; 2007: 663-668.

19. Uddin SJ, Nahar L, Shilpi JA, Shoeb M, Borkowski T, Gibbons S, Middleton M, Byres M, Sarker SD. Gedunin, a limonoid from Xylocarpus granatum inhibits the growth of $\mathrm{CaCo} 2$ colon cancer cell line in vitro, Phytotherapy Research 21; 2007: 757-761.

20. Kadota S, Marpaung L, Kikuchi T, Ekimoto H (1990) Constituents of the seeds of Swietenia mahagoni Jacq. 1. isolation, structures, and $\mathrm{H}-1$ nuclear and $\mathrm{C}-13$-nuclear magnetic resonance signal assignments of new tetranorterpenoids related to swietenine and swietenolide, Chemical and Pharmaceutical Bulletin 38: 639-651

21. Inada A, Konishi M, Murata H, Nakanishi T (1994) Structures of a new limonoid and a few triterpenoid derivative from pericarps of Trichilia connaroides, Journal of Natural Products 57: 1446-1449. 